\title{
PERFORMANCE OF GRASSLANDS PUNA CHICORY
}

T. J. Fraser, G. P. Cosgrove, W. J. Thomas, D. R. Stevens and M. J. Hickey Grasslands Division, DSIR, Lincoln, Palmerston North and Gore

Abstract

Four separate experiments evaluating Grasslands Puna chicory (Cichorium intybus) are reported. Three of these experiments used animals to measure the quality while the fourth looked at establishment and persistence on summer dry areas in Southland.

Liveweight gains both with calves and lambs were higher with Puna than could be expected with conventional pastures.

In an autumn trial lambs grazing Puna grew over $70 \mathrm{~g} /$ head/day faster than those grazıng rape.

Grasslands Puna established and persisted when sown in pasture mixtures in Southland. Production was maintained at a high level after three years of rotational grazing.

Keywords: Cichorium intybus; pasture quality; herbage allowance; animal performance

\section{INTRODUCTION}

Recent shifts in lamb marketing to a requirement for heavier carcasses has resulted in a search for pasture species that will give satisfactory lamb growth rates over the summer months. Earlier work has shown the very high herbage growth rates of Grasslands Puna chicory, (Cichorium intybus) under rotational grazing (Lancashire 1978; Lancashire \& Brock 1983). Herbage growth rates in excess of $200 \mathrm{~kg} / \mathrm{ha} /$ day have been recorded in summer in Manawatu (Hare et al. 1987).

This paper reports four evaluations of Puna, three looking at the potential of converting this herbage into satisfactory animal growth rates. The remaining study looks at the growth potential of Puna in Southland, an area where it has not been grown before.

$$
\text { EXPERIMENT } 1
$$

Bull beef growth rate on Puna at Aorangi experimental farm in Manawatu. This experiment was in two stages, 20 days duration from late February 1987 (PI) and a further 13 day grazing period from early May 1987 (P2). Both experiments compared two levels of herbage allowance, 50 and $100 \mathrm{~g} \mathrm{DM} / \mathrm{kg} \mathrm{LW} /$ day.

Eight Friesian bull calves were used per treatment, starting liveweights averaging $122 \mathrm{~kg}$ for $\mathrm{P} 1$ and $170 \mathrm{~kg}$ for P2. Pre and post trial liveweights were measured after 12 hours fasting. Calves were grazed on Puna prior to commencement of measurements.

Puna pastures were managed to give a herbage mass of about $3.5 \mathrm{t} \mathrm{DM/ha}$ and calves were shifted to new breaks three times per week.

Pre-grazing herbage mass averaged 3.5 t DM/ha and was similar for both allowances and both periods. Residual herbage mass was higher in high allowance (HA) than the low allowance (LA) (Table 1). Plants were at a uniform stage of maturity with few plants commencing stem elongation.

Mean daily dry matter intakes and liveweight gains are presented in Table 1. Lower intakes on LA than HA were apparent but differences were not significant. Liveweight gains were higher on HA than LA for both periods.

Level of herbage mass on the high allowance treatment was in the range of 2.0-3.5t DM/ha for both periods and was unlikely to limit intake. However, at the low allowance residual herbage masses down to 0.9 and $1.4 \mathrm{t}$ DM/ha would normally be expected to limit intake of pasture fed cattle (Nicol \& Nicoll 1987). Compared with the high allowance treatment, liveweight gain declined more severely than did intake on the low allowance treatment. It would appear that the erect and open growth habit of Puna allows grazing to a lower residual before intake is limited than is the case with a grass-clover pasture. 
Table 1: Effect of herbage allowance level on mean dailv intake and liveweiaht aain

\begin{tabular}{llcccccc}
\hline & \multicolumn{2}{c}{$\begin{array}{c}\text { Residual herbage mass } \\
\text { (t DM/ha) }\end{array}$} & \multicolumn{2}{c}{$\begin{array}{c}\text { Intake } \\
\text { (gm DM/kg LW) }\end{array}$} & \multicolumn{2}{c}{$\begin{array}{c}\text { Liveweight gain } \\
\text { kg/hd/day }\end{array}$} \\
& HA & LA & H A & LA & H A & LA \\
\hline Period 1 & 2.0 & 09 & 34.3 & 31.3 & $0.88^{\text {*t* }}$ & 0.39 \\
Period 2 & 2.0 & 1.4 & 37.0 & 27.8 & $0.93^{*}$ & 0.67 \\
\hline
\end{tabular}

"'t means significantly different $\mathrm{P}<0.05, \mathrm{P}<0.001$

$\dot{H} A=$ high allowance $(100 \mathrm{~g} D M / \mathrm{kg} L W /$ day $)$

$\mathrm{LA}=\mathrm{low}$ allowance $(50 \mathrm{~g} \mathrm{DM} / \mathrm{kg} \mathrm{LW} /$ day $)$

Actual allowances differed slightly due to small variations in herbage mass between breaks. For period 1 average allowances were 86 and $44 \mathrm{~g} \mathrm{DM} / \mathrm{kg} \mathrm{LW}$ and for period 2, 106 and $53 \mathrm{~g} \mathrm{DM} / \mathrm{kg} \mathrm{LW}$ for HA and LA respectively. That the higher average allowances offered in period 2 had little effect on intake or liveweight gain of the HA group indicates that feeding levels during period 1 were at optimum.

An allowance of $90 \mathrm{~g} \mathrm{DM} / \mathrm{kg} \mathrm{LW}$ was sufficient to give maximum liveweight gains in 6-8 month old calves, a similar allowance level for pasture. However, maximum gains from pasture of $0.6-0.7 \mathrm{~kg} / \mathrm{hd} /$ day reported by Nicol \& Nicoll (1987) are much lower than those recorded from Puna in this experiment.

\section{EXPERIMENT 2}

Lamb growth rates on Puna in spring at Lincoln, Canterbury. This experiment was over a six week period from early November 1986. Ten, eight week old Dorset $x$ Coopworth ram lambs were ad-lib fed Puna with a fresh break on a weekly basis. Herbage mass ranged from 5 to 10 t DM/ha.

The comparison for this experiment was similar grazing evaluations that have been carried out at Lincoln College using pure pasture species with Huia white clover (Trifolium repens L.) being the control (Cruickshank 1986)

Fasted lamb liveweight gains over a 42 day period averaged $12-16 \mathrm{~kg}$ (24-63 kg to $36-79$ $\mathrm{kg})$. This gave a daily weight gain of $290 \mathrm{~g}$ and compares with gains from other pure species in spring of $227 \mathrm{~g}$ for ryegrass ranging through to $320 \mathrm{~g}$ for white clover (Cruikshank 1986).

\section{EXPERIMENT 3}

Lamb growth rates on irrigated stands of Puna and Rangi rape (Brassica napus ssp. oleifera) in autumn at Lincoln, Canterbury. This experiment was over a nine week period from early February 1987. Two allowances of Puna were compared $-1.5 \mathrm{~kg}$ and $3 \mathrm{~kg} / \mathrm{head} / \mathrm{day}$ while only the high allowance ( $3 \mathrm{~kg} / \mathrm{head} /$ day) of Rangi was fed.

Mean herbage mass was $2500 \mathrm{~kg} / \mathrm{ha}$ for Puna and $3500 \mathrm{~kg} / \mathrm{ha}$ for Rangi. Lambs were given a fresh break on a weekly basis, break size being used to fix allowance. Twenty Coopworth ram lambs were randomly allocated to each treatment.

For both experiment 2 and 3 lambs were fasted for 24 hours prior to weighing at start and end of measurement period. All lambs were drenched to control internal parasites every three weeks.

Results from experiment 3 are given in Table 2.

These results indicate that even at relatively low herbage allowances the lambs grazing Puna have performed very well, particularly when it must be noted that lamb growth rates are

Table 2: Lamb performance on Puna and Rangi rape in autumn

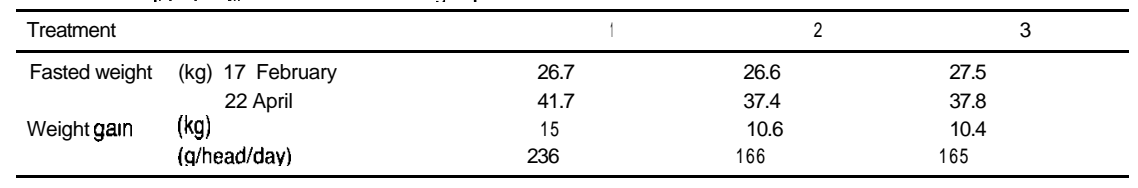

TREATMENTS: 1 Allowance $3.0 \mathrm{~kg} /$ head/day. Puna.

2 Allowance $\mathrm{t} .5 \mathrm{~kg} / \mathrm{head} / \mathrm{day}$. Pun.?

3 Allowance $3.0 \mathrm{~kg} / \mathrm{head} / \mathrm{day}$. Rangi. 
lower in autumn than in spring (D. Poppi, pers. comm.). Even at the low allowance (1.5 $\mathrm{kg} / \mathrm{head} /$ day) when residuals were down to $0.6 \mathrm{t} \mathrm{DM} / \mathrm{ha}$, Puna's growth habit allows for satisfactory animal performance.

\section{EXPERIMENT 4}

Establishment and persistence of Puna on summer dry soils in northern Southland. This experiment was on two soils near Riversdale, an area prone to summer drought. These were a free draining Hororata silt loam and a Kaweku silt loam prone to winter waterlogging. Annual rainfall ranged from 670 to $1095 \mathrm{~mm}$ over the trial duration with the Hororata soil being the drier of the two in each year.

Puna chicory was evaluated as a binary mixture with a grass and in a complex mixture. The sowing rates of the species used (Table 3 ) were adjusted in the complex mixtures to compensate for the speed of establishment. One complex mixture contained all species including Huia white clover and Pawera red clover, and the other was without the two most vigorous grasses (Nui and Matua), and Pawera.

Table 3: Sowing rates for binary and complex mixtures of Puna chicory, and mean growth scores for binary mixtures in Southland. (Scale $0=$ absent. $5=$ excellent).

\begin{tabular}{lccccccc}
\hline & Nui & Matua & Wana & Roa & Maru & Puna & S.E. mean \\
$\begin{array}{l}\text { Sowing Rate (kg/ha) } \\
\text { Binary mix }\end{array}$ & 18 & 60 & 15 & 30 & 20 & 10 & \\
$\quad$ Complex mix & 5 & 10 & 10 & 12 & 12 & 2 & \\
Mean growth score & & & & & & & \\
$\quad$ Establishment & $4.42 \mathrm{~b}$ & $4.08 \mathrm{~b}$ & $1.96 \mathrm{e}$ & $2.58 \mathrm{~d}$ & $3.17 \mathrm{c}$ & $4.96 \mathrm{a}$ & 0.143 \\
$\quad$ Year 3 & $4.04 \mathrm{a}$ & $3.17 \mathrm{~b}$ & $3.81 \mathrm{a}$ & $2.89 \mathrm{~b}$ & $1.84 \mathrm{e}$ & $4.03 \mathrm{a}$ & 0.204 \\
\hline
\end{tabular}

Plots were broadcast sown in October 1982. When measurements began in autumn 1983 plots were rotationally grazed throughout the year, laxly during late spring and summer $(18 \mathrm{~cm}-4 \mathrm{~cm})$ and hard during the rest of the year $(15 \mathrm{~cm}-1 \mathrm{~cm})$. Each site had an initial topdressing of $350 \mathrm{~kg} / \mathrm{ha}$ of potassic superphosphate (O-7-7-9). Following a soil nutrient test in winter 1983 annual topdressing of $250 \mathrm{~kg} / \mathrm{ha}$ of superphosphate (0-9-O-I 1) were applied each spring. Initial $\mathrm{pH}$ was 5.8 and no lime was used.

The paired mixtures were visually scored for growth on a scale of 0-5 (absent-excellent) at each grazing. Dry matter yields were measured at each grazing.

\section{Binary Mixtures}

During the establishment period all species contributed to the sown mixture according to their respective seedling vigour regardless of site (Table 3 ).

The rapid establishment and high sowing rate of Puna enabled it to dominate over the associated grasses, This relationship continued throughout the following three years (Table 3)

\section{Complex Mixtures}

The complex mixtures confirmed the potential of Puna as a productive supplement for summer pastures (Lancashire, 1978). The use of a lower seeding rate in these mixtures (Table 3) ensured that Puna was not as dominant and the balance of grass was much better (Table 4). Performance at either site was similar (Table 4) suggesting that Puna can survive winter wet soils if managed correctly which includes no winter grazing.

Plant densities did decline (Table 4) but relative yields remained similar averaging 30, 40 and $40 \%$ of annual production in the three years respectively. Winter growth of Puna was negligible (150 kg DM/ha) in this environment but the inclusion of Nui and Wana ensured adequate total winter herbage production. 
Table 4: Three year mean total yields, the proportionate contribution of Puna to total yield, and density of Puna plants in complex mixtures on two soil types in Southland.

\begin{tabular}{|c|c|c|c|c|c|c|}
\hline & \multicolumn{3}{|c|}{ Full mixture } & \multicolumn{3}{|c|}{ Part mixture } \\
\hline & Mar-Ott & Nov-Feb & Annual & Mar-Oct & Nov-Feb & Annual \\
\hline \multicolumn{7}{|l|}{ Kaweka Soil } \\
\hline Puna \% & 25 & 38 & 31 & 33 & 49 & 40 \\
\hline Yield (kgDM/ha) & 7530 & 6640 & 14170 & 6800 & 5390 & 12190 \\
\hline \multicolumn{7}{|l|}{ Hororata Soil } \\
\hline Puna \% & 24 & 45 & 33 & 34 & 44 & 39 \\
\hline Yield (kg DM/ha) & 7470 & 5490 & 12960 & 6190 & 4910 & 11100 \\
\hline Plant Density (Plants $\left./ \mathrm{m}^{\star}\right)$ & & 23.6 .83 & 26.1 .84 & 26.3 .85 & 3.3.86 & \\
\hline Kaweka Soil & & 47 & 44 & 38 & 28 & \\
\hline Hororata Soil & & 45 & 43 & 36 & 29 & \\
\hline
\end{tabular}

\section{CONCLUSION}

Grasslands Puna chicory is a plant that can have a major input into improving animal production. The summer and autumn animal liveweight gains are high and with the shift to heavier lamb carcasses this is a very important factor particularly when compared to the less than satisfactory animal performance from conventional pastures over this period.

With Puna's very high herbage production, persistence, and now its proven high animal performance, further work is justified on both management and companion species to find the extent and best use for this cultivar in New Zealand agriculture.

\section{Rolerences}

Cruikshank G.J. 1986. Nutritional constraints to lamb growth at pasture. Thesis Lincoln College.

Hare M.D., Rolston M.P., Crush J.R., Fraser T.J. 1987. Puna Chicory A perennial herb for New Zealand pastures. Proceedings Agronomy Society of NZ (in press).

Lancashire J.A. 1987. Improved species and seasonal pasture production. Proceedings NZ Agronomy Society 8: 123-128. Lancashire J.A., Brock J.L. 1983: Management of new cultivars for dryland. Proceedings NZ Grassland Association 44 61-73.

Nicol A.M., Nicoll G.B. 1987. Pastures for beef cattle. In Livestock feeding on Pasture. NZ Society of Animal Production Occasional publication 10: Chapt. 10 pp. 119-132. 